\title{
VÁLOGATÁS AZ ÓVODA-ISKOLA ÁTMENET EURÓPAI TAPASZTALATAIBÓL
}

\section{Golyán Szilvia}

Eötvös Loránd Tudományegyetem

Az Európai Uniós tagállamokban az óvoda-iskola átmenet okozta gondokat szerkezeti átalakításokkal, összefüggő curriculumokkal, az óvoda és az iskola, illetve az iskola és a családok szorosabb együttműködésével próbálják megoldani. Van olyan ország, ahol óvodai osztályokat hoztak létre az alapfokú iskolákban (Hollandia) vagy az iskola előtti nevelés utolsó évét, valamint az alsó tagozat első évét egy oktatási ciklusba vonták össze (Franciaország), másutt pedig többféle alternatívát is kipróbáltak annak érdekében, hogy az átmenet okozta gondokat megoldják (Svédország). Vannak azonban olyan tagállamok is, amelyekben nem jelentkezik az átmenet problémája (ilyen például Dánia, Norvégia, Írország, Izland vagy Spanyolország).

A továbbiakban tekintsük át röviden néhány európai ország iskola előtti és alapfokú iskolai oktatásának sajátosságait. Az adott ország közoktatási struktúrájának megismerését minden esetben ábra is segíti, ezek értelmezéséhez az 1. ábrán található jelmagyarázat az irányadó.

Természetesen jelen tanulmány keretein belül nem lehet célom, hogy minden egyes európai ország gyakorlatát bemutassam, így néhány olyan tagállam praxisát emelem ki a következőekben, melyek az óvoda-iskola átmenet szempontjából sajátosaknak tekinthetők. Így esett választásom az Egyesült Királyságra, ahol a legkorábban kezdődik a tankötelezettség és nincs kötelező óvodáztatás; Dániára, ahol működik iskolaelőkészítő osztály; Németországra, ahol az iskolába lépésnek nincs a tankötelezettségi életkor elérésén kívül más feltétele; Spanyolországra, ahol működik „óvodaiskola” jellegű intézmény; Franciaországra, ahol van úgynevezett előkészítő osztály; Írországra, ahol kiemelten foglalkoznak a hátrányos helyzetü gyermekek korai nevelésével; Csehországra, ahol nehézségeket okozott az előkészítő osztályok bevezetése; $s$ végül Romániára és Szlovákiára, ahol a nulladik évfolyam bevezetése nemrégiben történt meg, előbbi országban kötelező jelleggel, utóbbiban pedig alternatívaként.

\section{Az iskola előtti nevelés és az alapfokú iskoláztatás rendszere}

Egyesült Királyság

Az európai országok többségében a gyerekek hatéves életkorban kezdik meg az alapfokú iskolát. Az Egyesült Királyságban ez ötéves korra tevődik, ami alacsonyabb, mint az európai átlag, de az iskolakezdés a gyakorlatban még ennél korábban is megtörténhet. A hivatalos iskolaköteles kor Angliában és Walesben akkor kezdődik, amikor a gyermek betölti az ötödik életévét. De számos gyermek kezdi négyévesen az iskolát, mivel több iskola felveszi az úgynevezett befogadó 
osztályba (Reception Class) azt a diákot, aki az adott tanévben betölti az ötödik életévét ${ }^{1}$.

Angliában (2. számú ábra) és Walesben (3. számú ábra) nincs államilag szervezett, iskola előtti nevelési rendszer. Az iskola előtti nevelést vagy a helyi oktatási hatóságok vagy más magánszervek biztosítják ${ }^{2}$. A 3-5 éves gyerekeket szüleik vagy az óvodákba, vagy az elöbb említett alapfokú iskolák óvodai osztályaiba (Nursery Classes) írathatják be, ez az oktatási szakasz azonban nem kötelező. Az óvodákat és játszócsoportokat szülők, önkéntesek, illetve önálló szervezetek hozhatják létre, ezek többsége tandíjmentes ${ }^{3}$.

Az Egyesült Királyságban az ötéves kori iskolakezdés történeti gyökere az 1870-es oktatási törvényhez nyúlik vissza. Az életkor meghatározásakor heves parlamenti vita folyt, felmerült az esetlegesen hat- vagy akár hétéves korban történő iskolakezdés lehetősége is. A korai beiskolázás mellett a szociális támogatás kora gyermekkori szükségessége szolgált érvként, célként jelent meg, hogy kiemeljék a gyermekeket a hátrányos helyzetű családokból, illetve a kedvezötlen utcai körülmények közül. A szociális jellegü érv mellett volt egy politikai-gazdasági indíttatású szempont is, miszerint a korábban iskolát kezdő gyermekek hamarabb kerülnek be a munkaeröpiacra. Fontos megjegyezni, hogy az életkor meghatározásánál nem mérlegelték a személyiségfejlődéssel kapcsolatos vagy a pedagógiai megfontolásból eredő kritériumok meglétét. Többek között a fent említett törvény vezette be az általános tankötelezettséget és a maga korában korszerü tantervet, valamint ettől az időtől kezdve csökkent az oktatásban az egyház szerepvállalása (Sharp, 2002).

Skóciában (4. számú ábra) a 3-5 éves gyerekeket az oktatásügyi hatóságok által felügyelt gyermekmegörzők, valamint önkéntes alapon szerveződő vagy önálló szervezetek által müködtetett óvodák fogadják. Az oktatásnak ez a szakasza nem kötelező és müködhet egész vagy félnapos rendszerben. ${ }^{4}$

Észak-Írországban (5. számú ábra) a 3-4 évesek óvodai oktatását az úgynevezett „Education and Library Boards”-ok, az óvodák és az alapfokú iskolákban müködő óvodai osztályok biztosítják ${ }^{5}$. A tankötelezettség, az összes európai országot összevetve, a legkorábban itt kezdődik, négyéves korban. Az 1989-es oktatási reform rendelkezésének értelmében a tankötelezettség időtartama 12 évre nőtt, azaz ma 4 éves kortól 16 éves korig tart. Az a kisgyermek, aki betölti

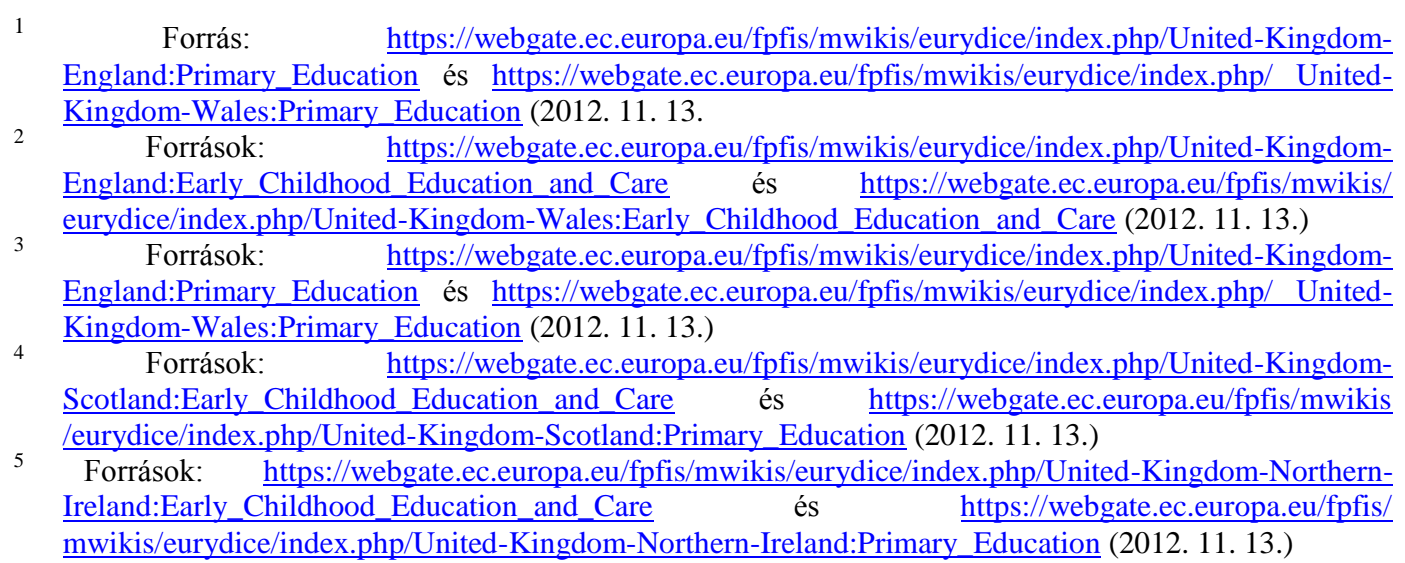


az adott évben 4. életévét, vagy az adott év július 1-jéig eléri azt, annak meg kell kezdenie alapfokú iskolai tanulmányait (Sharp, 2002).

Az Egyesült Királyságban tehát az iskolakezdés életkortól függ, s ennek megfelelően a gyermekek közelítőleg homogén életkori osztályokban tanulnak.

Az Egyesült Királyságban kutatások során kerestek összefüggést a gyermek életkora és az iskoláztatás időtartama, valamint a gyermek későbbi tanulmányi elömenetele között. Abból az evidenciából indultak ki, hogy átlagosan egy adott osztályban a fiatalabb gyerekek kevésbé jól teljesítenek (föként a nyári születésűek). Ennek kapcsán vizsgálták, hogy ez a kezdeti különbség jelentős-e, illetve megmarad-e a későbbiek során. Kutatásokkal támasztották alá, hogy a gyermek életkora és az iskoláztatás időtartama az a két tényező, amely leginkább hatással van a későbbi iskolai teljesítményre. Peter Tymms és munkatársai (1997, 2000, idézi: Sharp, 2002; Tymms, Jones, Merell, Henderson és Cowie, 2005) longitudinális módszerrel ezer kisdiákot mértek. Azt tapasztalták, hogy a gyermek életkora erősen korrelál a gyermek tudásával. Beigazolódott, hogy azok a gyermekek, akik idősebbek voltak az adott osztályokban, azoknak a matematikai és olvasási eredményei is jobbak voltak a fiatalabbakhoz viszonyítva. Érdekes eredménye vizsgálatnak, hogy az adott osztályban az idősebb gyermekek matematikai teljesítménye kissé jobban emelkedett az első-második évfolyamon a bevezető (nulladik) évfolyamhoz képest, mint a náluk fiatalabbakénak.

Foglalkoztak azzal a kérdéssel is, hogy a rugalmasabb iskolakezdés segíthetne-e, mivel azt tapasztalták, hogy vannak olyan négyéves gyermekek, akik nem érettek az iskolakezdésre. Azt találták, hogy esetleg a fiúknak, továbbá a kisebbségi gyermekeknek ajánlható, hogy pedagógusi javaslat alapján egy évvel később kezdjék meg az alapfokú iskolát. Összességében - mindezt nemzetközi (elsősorban amerikai) kutatásokra alapozva kellően igazoltnak is vélték az idézett kutatók - az a vélemény körvonalazódott, hogy nem ad jelentős elönyt (bár hátránnyal sem jár), ha a gyermek egy évvel később kezdi az alapfokú iskolát. Továbbá megjegyzik, hogy egy olyan osztály, ahol különböző életkorú gyermekek járnak együtt, a pedagógus számára is jelentősen több nehézséget okoz (Sharp, 2002).

\section{Dánia}

Dániában (6. számú ábra) 1990 óta van lehetőség arra, hogy az önkormányzat mellett egyesületek, szülők és vállalkozások is alapíthassanak kisgyermekkori intézményeket. ${ }^{6}$

Az iskola elötti nevelés dán rendszere többféle intézményt foglal magába. Megkülönböztetnek önkormányzati „gyermekmegőrzőket” (családi napközi), önkormányzati napközi otthonokat (ez lehet bölcsőde, óvoda és úgynevezett életkor alapján ,integrált” intézmény), magán fenntartású napközi otthonokat, magán „gyermekmegőrzőket”, és a társadalombiztosítás által támogatott magánóvodákat. A bölcsőde (Créch, Vuggestuer) 6 hónapos kortól 3 éves korig

$6 \quad$ Forrás: $\quad$ https://webgate.ec.europa.eu/fpfis/mwikis/eurydice/index.php/Denmark:Early Childhood Education and Care (2012. 12.13.) 
fogadja a gyermekeket, óvodai nevelésben 3 éves kortól 5-6 éves korig, míg a vegyes életkorú gyermekekkel foglalkozó intézményekben 1 éves kortól 5-6 éves korig vehetnek részt. 2009-es statisztikai adatok alapján Dániában a 3 és 5 év közötti gyermekek 97\%-a részesül napközbeni kisgyermekellátásban, egy 2011-es adat szerint pedig a kisgyermekek iskola előtti nevelésével foglalkozó intézmények több mint $60 \%$-a, míg az alapfokú iskoláknak több mint $85 \%$-a volt állami fenntartású ${ }^{7}$. Az állami iskolákban az oktatás ingyenes, a magániskolákban a teljes költség közelítőleg 10-30\%-át a szülők fizetik ${ }^{8}$.

A 2004-től hatályos szabályozás minden kisgyermekneveléssel foglalkozó intézmény számára előírja nevelési program kidolgozását. Az iskola előtti nevelési intézmények a családi nevelést egészítik ki oly módon, hogy személyiség- és kreativitásfejlesztő tevékenységeket szerveznek a gyermekek számára. Az „óvodai osztályok” vagy a nulladik osztály elsősorban inkább az iskolai rutinra készítik fel a gyerekeket, és kiemelten kezelik a társakkal való együttmüködésre való felkészítést. Az ,óvodai osztályokban” tanuló gyerekek a Folkeskole legalsóbb osztályának megfelelő oktatásban részesülnek, úgynevezett iskolaelőkészítő jelleggel.

Dániának komprehenzív iskolarendszere van. A Folkeskole fő elve, hogy a diákok életkorilag homogén osztályba járjanak. Céljuk, hogy minden gyermeknek biztosítsák a teljes, harmonikus fejlődéshez és tanuláshoz szükséges feltételeket. A Folkeskole ${ }^{9}$ magában foglalja a tankötelezettség teljes időtartamát, egységes szerkezetben (10 éves időtartam). 2008 óta minden gyermek számára a tankötelezettség 6 éves korban kezdődik és 16 éves korig tart. Egy gyermek abban az évben válik tankötelessé, amely év augusztus 1-jéig betölti a 6. életévét. A szülők kérésére vagy az ő beleegyezésükkel egy évvel késleltethető a tankötelezettség teljesítésének megkezdése, amennyiben azt a gyermek fejlettsége indokolja.

Dán kutatók az iskolakészültség tényezőinek vizsgálata mellett foglalkoznak azzal is, hogyan készülhet fel az iskola az óvodás gyermekekkel való „találkozásra” (Broström, 2000a). Alapvető céljuk az iskolakezdéssel összefüggő átmenet szempontjából elősegíteni, hogy a gyermek érezze jól magát az iskolában. Ehhez elengedhetetlen, hogy sikeresen alkalmazkodjon az óvodából az iskolába való átmenet okozta változásokhoz (Broström, 2000b).

\footnotetext{
7 Forrás: http://www.dst.dk/en/Statistik/emner/fuldtidsuddannelser/grundskoleuddannelser.aspx (2012. 12. 13.) Structure_Education_\%28Integrated_Primary_and_Lower_Secondary_Education\%29 (2012.12. 13.)

${ }^{9}$ A Folkeskole intézménytípust 1814-ben hozták létre, akkor hétéves korban kezdték az alapfokú iskolát a gyermekek, 2014-ben ünneplik az intézményrendszer fennállásának 200. évfordulóját.
} 


\section{Németország}

Németországban (7. számú ábra) az iskola előtti nevelés színtere főként a 36 évesek számára létrehozott óvoda (Kindergärten), amely a gyerekek iskolai előkészítésének hagyományos formája, de az óvodai nevelésben való részvétel nem kötelezö ${ }^{10}$. Több tartományban lehetőség van arra, hogy a tanköteles korú, de az iskolakezdésre még nem érett gyermekek úgynevezett óvodaszerü iskolákba járjanak (Schulkindergärten és Vorklassen). Egyes tartományokban, és azokban is csak meghatározott számú iskolában, a „Vorklassen”-ek az alapfokú iskolákhoz kapcsolódva fogadják az ötéves gyerekeket ${ }^{11}$.

Németországban tartománytól függetlenül minden hatodik életévét betöltött gyermek tankötelessé válik, s a kötelező iskolai oktatás a gyermek 16. életévéig tart.

Az 1990-es gyermek- és ifjúságvédelmi törvény (Kinder- und Jugendhilfegesetz) elsőbbséget adott a nem állami testületeknek (többnyire egyházaknak, gyermekjóléti alapítványoknak, szülöi közösségeknek) a kisgyermekkori nevelést magában foglaló különböző intézménytípusok alapításának és müködtetésének tekintetében. Ennek értelmében a helyi hatóságoknak (Kommunen) csak abban az esetben kell kisgyermekek számára gondozó-nevelő intézményt létrehozniuk, ha a magánintézmények nem biztosítanak megfelelőeket avagy ilyen intézmények nem állnak rendelkezésre. 2009-ben az említett törvény hatására az óvodák majdnem 70\%-át Németország nyugati tartományaiban már nem állami testületek müködtették. Fontos megjegyezni, hogy az állami és a nem állami intézmények müködésükhöz egyaránt kapnak az államtól pénzügyi támogatást. ${ }^{12}$

Az alapfokú oktatás tekintetében a magánfenntartású intézmények alapítását szigorú feltételekhez köti az Alaptörvény (Grundgesetz ${ }^{13}$ ).

Müködési engedélyt kaphat az intézmény, ha valamely pedagógiai irányzathoz kötődik (a legtöbb ilyen intézmény a Waldorf pedagógiai irányzathoz kapcsolódik - Freie Waldorfschulen ${ }^{14}$ ), illetve müködhetnek közösségi (Gemeinschaftsschulen) és felekezetek által fenntartott iskolák.

Németországban az 1997-es iskolakezdési koncepció értelmében az iskolába lépést már nem kötik fejlettségi feltételhez, minden tanköteles gyermeket beiskoláznak. Úgy vélik, hogy az iskolaérettség megállapítása egyfajta szelekciót eredményezne, így ehelyett inkább az integrációt, az inkluzív nevelést kívánják

\footnotetext{
10 Forrás: $\quad$ https://webgate.ec.europa.eu/fpfis/mwikis/eurydice/index.php/Germany:Early_ Childhood_Education_and_Care (2012.12.13.)

${ }^{11}$ Forrás: https://webgate.ec.europa.eu/fpfis/mwikis/eurydice/index.php/Germany:Primary Education (2012. 12. 13.) Childhood Education and Care (2012.12.13.)

13 Forrás: http://www.bundestag.de/bundestag/aufgaben/rechtsgrundlagen/grundgesetz/index.html (2012. 11. 10.)

14 Részletes információ a németországi Waldorf intézményekröl az alábbi oldalon található: http://www.waldorfschule.de/ (2012. 12. 13.)
} 
megvalósítani, és annak keretében tekintettel lenni az eltérő egyéni fejlettségi szintekre. $^{15}$

\section{Spanyolország}

Spanyolországban (8. számú ábra) az iskola előtti nevelés (Educación infantil) az oktatási rendszer részét képezi. Nem kötelező, és két szakaszra oszlik: 3 éves korig (Guarderia), valamint 3 éves kortól 6 éves korig (Escuela Infantil) tart. Az állami intézményekben az iskola elötti nevelés ingyenes ${ }^{16}$.

Az általános iskolai oktatás (Educación Primaria) háromszor kétéves ciklusra oszlik: az első ciklus 6-8 éves korig, a második ciklus 8-10 éves korig, a harmadik ciklus pedig 10-12 éves korig tart. Az első ciklus végén, ha a gyermek nem érte el a továbblépéshez szükséges fejlettséget, akkor egy évet meg kell ismételnie $^{17}$.

A 2002-es oktatási törvény ${ }^{18}$ (Ley de Organica Calidad de la Educación) bizonyos elöírásai minden tartományra nézve kötelezőek, ilyen például a kötelező és ingyenes oktatás a 6-12 éves gyerekek számára; de emellett a 17 tartománynak lehetősége van arra, hogy bizonyos keretek között ugyan, de kialakíthassa saját oktatási rendszerét.

A kora gyermekkori nevelés célja a gyermekek testi, érzelmi, szociális és intellektuális fejlesztése. A 3-6 éves gyermekek nevelésével foglalkozó óvodák gyakran kapcsolódnak egy általános iskolához, „óvodaiskola” jelleggel, komplex módon müködnek (Colegios de Educación Infantil y Primaria). Bár az iskola előtti nevelés nem kötelező, mégis sok szülő íratja be gyermekét, leggyakrabban az 5-6 évesek vesznek részt úgynevezett óvodai nevelésben ${ }^{19}$.

\section{Franciaország}

Franciaországban (9. számú ábra) az iskola előtti oktatásnak régi hagyományai vannak. A gyermekek kétéves kortól írathatók be az óvodákba (école maternelle), mely intézmények hatéves korukig foglalkoznak nevelésükkel. Az Európai Közösség országai közül, Belgiumot kivéve, Franciaországban a legnagyobb az óvoda intézményét igénybe vevők százalékos aránya, az ötévesek közel $100 \%$-a jár óvodába ${ }^{20}$.

Abban az esetben, amikor nincs lehetőség önálló óvoda létrehozására, akkor az általános iskolákhoz kapcsolódó gyermekcsoportok müködnek. Az óvodai nevelés nem kötelező és az állami intézményekben ingyenes. Az óvodáknak csak kis része van magánkézben, de ezek az intézmények is kapnak támogatást az

\footnotetext{
${ }^{15}$ Forrás: https://webgate.ec.europa.eu/fpfis/mwikis/eurydice/index.php/Germany:Primary_Education (2012. 12. 13.)

$16 \quad$ Forrás: https://webgate.ec.europa.eu/fpfis/mwikis/eurydice/index.php/Spain:Early_Childhood Education_and_Care (2012.12.13.)

${ }^{17}$ Forrás: https://webgate.ec.europa.eu/fpfis/mwikis/eurydice/index.php/Spain:Primary_Education (2012. 12. 13.)

${ }^{18}$ A törvény az alábbi oldalon megtekinthető: http://www.filosofia.org/mfa/2002loce.htm (2012. 12. 13.)

19 Forrás: https://webgate.ec.europa.eu/fpfis/mwikis/eurydice/index.php/Spain:Early_Childhood

20 Education_and_Care (2012. 12.13.)

20 Forrás: https://webgate.ec.europa.eu/fpfis/mwikis/eurydice/index.php/France:Early_Childhood Education and Care (2012. 12. 13.)
} 
államtól és a régiótól egyaránt, és a szülők is hozzájárulnak a fenntartás költségeihez. Az óvodai nevelés az alapképzés első ciklusának felel meg.

Az általános iskolai oktatás (école élémentaire) öt évig, 6-tól 11 éves korig tart. Az iskolaalapozó szakasz már az óvoda utolsó évében megkezdődik, biztosítva az iskolába való gördülékeny átmenetet. $\mathrm{Az}$ általános iskola öt tanulmányi évét két szakaszra osztják. Az első szakasz az előkészítő évből és az általános iskola első évéből, a második szakasz pedig a további három évből áll. ${ }^{21}$.

$\mathrm{Az}$ 1989-es oktatási kerettörvény ${ }^{22}$ (D'orientation sur l'éducation) bevezetése óta lehetőség nyílik arra, hogy a „koraérett”, társaiknál értelmileg fejlettebb gyermekek a törvényben elöírt 6. életévük elött, már az óvoda utolsó évében megkezdhessék az elemi iskola első ciklusát, úgynevezett előkészítő osztályba (cours préparatoire) léphetnek (Bajomi, 1991). A törvény többek között elöírta a minden tanuló számára egyaránt kötelező egyéni fejlesztés gyakorlatának a bevezetését.

A korábbi iskolakezdés lehetőségét vizsgálva azt tapasztalták, hogy a korai átmenet lehetőségével a gyakorlatban igen kevés és társadalmilag jól tipizálható gyermek (véleményem szerint inkább szülő) él. A lehetőség mérlegelésénél a családok önszelekciós mechanizmusa érvényesül: minél alacsonyabb a család társadalmi helyzete, annál kevésbé élnek a „kivétel”, azaz a korábbi iskolakezdés lehetőségével (Leroy és Audouin, 1995).

Írország

Írországban (10. számú ábra) - a többi európai országgal ellentétben nincsenek óvodák vagy más, iskola előtti nevelést biztosító oktatási intézmények, nincs óvodarendszer, nem rendelkeznek kisgyermekkori nevelési tradíciókkal. Az iskola előtti nevelési intézmények (ezek lehetnek bölcsődék, óvodák, játszócsoportok, családi napközik egyaránt) elsősorban jótékonysági alapon müködnek. A kormány ezeknek az intézményeknek semmilyen támogatást nem nyújt, mivel nem részei a hivatalos oktatási rendszernek, igénybevételük esetén minden költség a szülőkre hárul. Az általános iskolai oktatásban való részvétel azonban ingyenes ${ }^{23}$.

Írországban a tankötelezettség 6 éves kortól 16 éves korig tart. A gyermekeknek 4 éves kortól lehetőségük van alsó tagozatos iskolába, a korosztályuknak megfelelő program szerint müködő osztályokba járni (National Schools). Ennek az iskolatípusnak az első ciklusát a 4-6 éves korosztály számára hozták létre: Junior Infants (4-5 éves korig) és Senior Infants (5-6 éves korig). Ezekben az osztályokban iskolát megelőző, úgynevezett iskolaelőkészítő képzés

${ }^{21}$ Forrás: https://webgate.ec.europa.eu/fpfis/mwikis/eurydice/index.php/France:Primary_Education (2012. 12. 13.)

${ }^{22}$ A dokumentum megtekinthető az alábbi oldalon: http://dcalin.fr/textoff/loi_1989.html (2012. 12. 13.)

23 Forrás: https://webgate.ec.europa.eu/fpfis/mwikis/eurydice/index.php/Ireland:Early Childhood Education_and_Care és https://webgate.ec.europa.eu/fpfis/mwikis/eurydice/index.php/ Ireland:Primary Education (2012. 12. 13.) 
müködik, ami csak 5 éves kortól kötelező, de a szülők nagy része igénybe veszi már a gyerek 4 éves korától ${ }^{24}$.

Az általános iskolai oktatás során a készség- és képességfejlesztés mindenekfelett, a középpontban áll, amit a tanítók és az őket segítő pedagógiai asszisztensek (akár többen is egy adott osztályban) változatos módszerekkel, egyéni és kiscsoportos foglalkozásokkal igyekeznek támogatni. Az iskolai környezetben nincs játszósarok, illetve az óvodai környezethez hasonlító berendezés sem található.

Az „Early Start” program, a „Rutland Street” projekt, valamint az úgynevezett „Vándorló óvoda” program néhány példa azon speciális koragyermekkori szolgáltatások közül, melyekkel a hátrányos helyzetben élő, az oktatásból való kizárás veszélyének leginkább kitett, illetve vándorló családok gyermekeinek korai oktatását kívánják segíteni.

\section{Románia}

Romániában (11. számú ábra) az iskola előtt nevelés nem képezi részét a tankötelezettségnek, de müködnek állami és magánóvodák is (Grădiniţa). Egyegy életkorilag homogén óvodai csoportba átlagosan 15 kisgyermek jár ${ }^{25}$.

Romániában az elmúlt években a kisgyermekkori nevelés iránti szakmai érdeklődés jelentősen megnőtt. Ezt tükrözi a 2003-as „Kisgyermeknevelési nemzeti stratégia" (Strategii Naţionale pentru Educaţie Timpurie), a „Kisgyermeknevelési reform 2006-2011” (Proiectului de Reformă a Educaţiei Timpurii 2006-2011), valamint az „Inkluzív kisgyermeknevelési projekt 20062011" (Proiectului pentru Educaţie Timpurie Incluzivă 2006-2011). A nagyobb településeken számos óvoda közül választhatnak a szülők, több óvoda müködik speciális oktatási programmal, úgymint korai nyelvtanítás vagy sport specializáció. Minden faluban van legalább egy óvoda, mely általában normál nevelési programmal várja a helyi gyerekeket. Az óvodai felvételnél, a férőhelyek korlátozott száma miatt, figyelembe veszik a gyermek életkorát, a család lakóhelyének az óvodától való távolságát, továbbá az óvodás korú testvérek számát. A speciális nevelési szükségletű gyermekeket az óvodák befogadják, diagnózisuknak megfelelő fejlesztésüket kisegítő pedagógus végzi ${ }^{26}$.

A 2008-as új „Nemzeti alaptanterv” (Curriculum Naţional) az óvodai nevelés főbb céljai között megfogalmazta az iskolakezdéshez és az iskolai élethez szükséges ismeretek, készségek, képességek, attitüdök kialakítását. Óvodás korban a gyermekek mérése, munkájuk minősítése nem megengedett, az óvodás korú gyermekek bátorító nevelését támogatják, ami segíti a pozitív énkép kialakulását, fejleszti az egyéni képességeket és biztosítja az egyéni ütemhez igazodó fejlődést. Az óvodai csoportok életkorilag homogének, nem megengedett

${ }^{24}$ Forrás: https://webgate.ec.europa.eu/fpfis/mwikis/eurydice/index.php/Ireland:Primary_Education (2012. 12. 13.)

25 Forrás: $\quad$ https://webgate.ec.europa.eu/fpfis/mwikis/eurydice/index.php/Romania:Early Childhood_Education_and_Care (2012.12.13.)

${ }^{26}$ Forrás: https://webgate.ec.europa.eu/fpfis/mwikis/eurydice/index.php/Romania:Primary_Education (2012. 12. 13.) 
az „évismétlés”. Az óvodai nevelés gyakorlatában megtalálható a „Lépésről lépésre" program, a Waldorf, a Montessori és a Freinet pedagógiai szemlélet, valamint a Jena Plan-koncepció.

Az általános iskolai oktatás szakasza a tankötelezettség része, mely állami és magánintézményekben egyaránt megvalósulhat; de általános iskolát alapíthatnak gazdasági társaságok, magánszemélyek és természetes jogi személyek is ${ }^{27}$.

A többször módosított 1995-ös „Nemzeti oktatási törvény” értelmében az a kisgyermek, aki az adott tanév kezdetéig betölti a hatodik életévét, megkezdi tankötelezettségének teljesítését az általános iskolában. Szülö/gondviselö írásos kérvénye alapján az a gyermek is megkezdheti az adott évben az iskolát, aki a naptári év végéig tölti be hatodik életévét és fejlettségi szintje megfelel az általános követelményeknek. Mindemellett szülöi/gondviselöi kérésre a tankötelezett gyermek iskolakezdésének időpontja halasztható. Az iskolakészültségi szintet meghatározza: a gyermek egyéni szintje, a családi háttér, az iskola elött nevelés színvonala, valamint a közösség (Ionescu, 2007).

2011. január 10-én jelent meg az új román „Nemzeti oktatási törvény” (Legea educatiei nationale) $^{28}$, amely átfogó reformokat szándékozott beépíteni a román oktatási rendszerbe. A jogszabály értelmében 2012 szeptemberétől a hatéves koruktól iskolaköteles gyerekeknek az első osztály előtt egy évig iskolaelőkészítő osztályba kell járniuk ${ }^{29}$. A köznyelvben „nulladik” osztályként emlegetett oktatási forma a 2012/2013-as tanítási év szeptemberében indult be. A „nulladik” osztály célja, hogy felkészítse a gyerekeket a közösségi életre és fejlessze kommunikációs készségeiket. Ezeket a feladatokat az óvodai előkészítő csoportok is ellátták, de az óvoda nem volt kötelező. A nulladik osztály beindításának egyik fontos célkitüzése, hogy a gyerekek számára könnyebbé váljék az átmenet az óvoda és az iskolai képzés között azáltal, hogy a módszertan főként gyakorlati tevékenységekre és a játékra alapoz.

Az előkészítő osztályokba azok a gyerekek kerültek, akik a tanévkezdésig betöltötték a hatodik életévüket, de szülöi kérésre - ha a gyermek szellemiérzelmi fejlettsége lehetővé tette - azok is megkezdhették az alapfokú iskolát, akik a naptári év végéig töltik majd be ezt az életkort. Előírták, hogy az előkészítő osztályokban nem taníthatnak szakképzetlen vagy kezdő pedagógusok. A gyerekek nem kapnak osztályzatokat és minősítéseket. A törvény rendelkezik arról is, hogy az iskolák elsősorban a körzetükhöz tartozó gyerekeket vegyék fel.

\footnotetext{
${ }^{27}$ Forrás: https://webgate.ec.europa.eu/fpfis/mwikis/eurydice/index.php/Romania:Primary Education (2012. 12. 13.)

${ }^{28}$ A dokumentum megtekinthető az alábbi oldalon: http://www.edu.ro/index.php/legaldocs/14847 (2012. 12. 13.)

${ }^{29}$ Az oktatáspolitikai irányítók a bevezetéssel párhuzamosan fontolgatják, hogy a 2013/2014-es tanévtől eltörlik az iskolaelőkészítő osztályokat.
} 


\section{Csehország}

Csehországban (12. számú ábra) a tankötelezettség 6 éves kortól 15 éves korig tart. Ez magába foglalja az óvoda utolsó évét, az általános iskolát, valamint a középiskolát. Az óvoda (mateřská škola) az oktatási rendszer része.

Az óvoda 3 éves kortól 6 éves korig tart, nem kötelezö, bár e korcsoport körülbelül 90\%-a jár óvodába. Az óvodáztatás alapvetően ingyenes, de a szülöket kérhetik, hogy járuljanak hozzá a működési költségekhez. Az iskola elötti év azonban mindenki számára ingyenes és kötelező. Fenntartó tekintetében szinte teljes mértékben az állam van jelen, az egyházi vagy magán intézményfenntartók száma elenyésző. ${ }^{30}$

Csehországban lehetőség van a szabad iskolaválasztásra. Az általános iskolai oktatás két részből áll: az első szakasz 6-tól 11 éves korig tart, a második szakasz 11-töl 15 éves korig. Az oktatás alapja a 2005-ös „Oktatási kerettörvény” (Rámcový vzdělávaci program pro základní vzděláváni). A gyerekek a hatodik életévük betöltését követöen válnak tankötelessé, de a tankötelezettség megkezdése halasztható, illetve korábbra is hozható. Az elörehozott iskolakezdés gyermekorvosi és pszichológusi véleményhez kötött. ${ }^{31}$ Kutatás keretében vizsgálták, hogy az iskolát megelöző intézményes nevelés tartalmi elemei milyen összefüggést mutatnak a gyermekek iskolakészültségi mutatóival (Šmelová és Souralová, 2010). A kutatás keretében megkérdezett pedagógusok véleménye szerint az óvodából érkező gyerekek szociokulturális és interperszonális területen a legfejlettebbek, míg az elmúlt három év átlagában pszichés éretlenséggel találkoztak a leggyakrabban (ennél valamivel kevesebbszer a szociális éretlenséggel és csak minimális esetben a biológiai éretlenséggel). Szintén kevés esetben (12\%) fordult elő, hogy bár érett volt a gyermek az iskolakezdésre, a szülők mégis a késleltetett beiskolázás mellett döntöttek (Šmelová és Souralová, 2010).

A hátrányos helyzetű és roma gyerekek számára úgynevezett előkészítő osztályokat indíthatnak az óvodák, az alapfokú és a speciális iskolák egyaránt. Ezen osztályok indításának alapvető célja azt volt, hogy az ide járó gyermekeket felkészítse az iskolakezdésre, de ma már bírálják a rendszert, mivel a speciális iskolában lévő gyermekek többsége a tanulmányait is ott folytatja, így teremtve meg a korai szegregáció lehetőségét. Csehországi kutatók véleménye szerint az inkluzív nevelés gyakorlatban való elterjedését akadályozza egyrészt a társadalom „,nem támogató” hozzáállása, másrészt a merev cseh iskolai gyakorlat - az utóbbi a pedagógusok nem megfelelőnek ítélt felkészítéséből és a szükséges iskolai feltételek hiányából eredeztethető (Straková, Simonová és Polechová, 2011).

\footnotetext{
30 Forrás: $\quad$ https://webgate.ec.europa.eu/fpfis/mwikis/eurydice/index.php/Czech-Republic:Early Childhood Education and Care (2012. 12.13.)

Forrás: $\quad$ https://webgate.ec.europa.eu/fpfis/mwikis/eurydice/index.php/Czech-Republic: Single_Structure_Education_\%28Integrated_Primary_and_Lower_Secondary_Education\%29 (2012. 12. 13.)
} 


\section{Szlovákia}

Szlovákiában (13. számú ábra) az iskola előtti nevelési rendszer pedagógiai szemléletváltás nyomán újul meg napjainkban. Az óvodai nevelésben való részvétel nem kötelező. A „Tatran” alternatív óvodai és iskolai programmal, illetve a drámaprojekttel is dolgoznak, továbbá számos óvoda használja a „Lego Dacta" programot. ${ }^{32}$

A tankötelezettség időtartama tíz év, 6-tól 16 éves korig tart. Az általános iskolai képzés, amely a gyermeket a további tanulmányokra készíti fel, két részből áll: az 1-4. évfolyamos alsó tagozatból és az 5-9. évfolyamot felölelö felső tagozatból. Az alsó tagozat elvégzését követően a diák választhat, hogy tanulmányait nyolcosztályos gimnáziumban vagy az általános iskola felső tagozatán kívánja folytatni. ${ }^{33}$

$\mathrm{Az}$ általános iskolai képzés ingyenes az állami intézményekben, míg a magániskolák tandíjat kérhetnek. Utóbbi esetben a tandíj mértéke az iskola vezetésétől függ.

Az állam által támogatott módszertani program a „Škola dokorán” (Nyitott iskola), és a „Krok za krokom” (Lépésről lépésre). Ezek a projektek hatékonynak bizonyultak mind a roma gyermekek, mind pedig az ingerszegény családi háttérrel rendelkező diákok nevelésében. A 245/2008. számú oktatási törvény értelmében a gyermek, ha eléri a hatéves kort és iskolaérett, rendszerint megkezdi tankötelezettségét. Az általános iskolai képzés 9 évig tart, azonban a 2008/2009-es tanítási évtől kezdődően lehetőség van egy úgynevezett nulladik osztályban való részvételre. Az általános iskola nulladik évfolyamára olyan gyermekek járhatnak, akik az adott év szeptember 1-jéig betöltik a tankötelezettségi korhatárt, azaz a hatodik életévet, de nem érik el az iskolaérettségi szintet (testi és mentális fejlettség) és/vagy hátrányos szociális háttérrel rendelkeznek. Az igazgató dönt arról, hogy a gyermek még egy évet az óvodában maradjon-e vagy megkezdje tankötelezettségét a nulladik évfolyamon - a szülö/gondviselő egyetértésével. Legkésőbb annak a tanévnek a kezdetén, amikor a gyermek betölti a 8. életévét, meg kell kezdenie a tankötelezettség teljesítését az első osztályban vagy szülő/gondviselő hozzájárulásával a nulladik osztályban.

A nulladik osztály mintegy átmenetet biztosít az óvoda és az iskola között, minthogy az óvodai munkára épít, s a fejlesztés dominál benne. Nem írni és olvasni tanítanak, hanem az íráshoz-olvasáshoz szükséges készségeket, képességeket fejlesztik, szokásrendszert alakítanak ki. A fejlesztőmunka az egyes készségek „csiszolására” irányul, illetve a kimaradt mozzanatok „felépítésére” törekszik, segíti a gyermek alkalmazkodását az iskolai tanulási tevékenységhez, a követelmények „világához”, hogy az első osztály zökkenőmentesebb legyen számára.

\footnotetext{
32 Forrás: https://webgate.ec.europa.eu/fpfis/mwikis/eurydice/index.php/Slovakia:Early_Childhood 33 Education_and_Care (2012. 12.13.)

Forrás: $\quad$ https://webgate.ec.europa.eu/fpfis/mwikis/eurydice/index.php/Slovakia:Single_Structure Education \%28Integrated Primary and Lower Secondary Education\%29 (2012. 12. 13.)
} 
Azokon a településeken, ahol nincs lehetőség teljes, kilenc évfolyamos általános iskolai rendszer müködtetésére (ennek feltétele a 150 tanuló megléte), ott - minimum 30 fős gyermeklétszám esetén - müködhet az általános iskola alsó szintje osztatlan képzési rendszerben is, s a diákok folytathatják, illetve befejezhetik tanulmányaikat más, kilenc évfolyamos iskolákban. Mindezek értelmében „teljes szerkezetu”” és „nem teljes szerkezetu”” általános iskolák múködnek Szlovákiában.

\section{A napközbeni kisgyermekellátás és -nevelés struktúrája}

Az OECD 1998 és 2000 között átfogó vizsgálatot ${ }^{34}$ végzett 12 országban a kisgyermekellátás és -nevelés helyzetéről. A nemzetközi adatokat és információkat azzal a céllal gyüjtötték össze, hogy a tapasztalatok elemzését követően javítani lehessen a kisgyermekellátásra és -nevelésre, a gyermekek tanulására irányuló politika tervezését és megvalósítását. A vizsgálat során tanulmányozták egyrészt az adott országok fóbb politikai megfontolásait, a törvényi, rendeleti szabályozást és a kisgyermekellátás helyzetét, társadalmi környezetét; másrészt a kormányok, önkormányzatok, nonprofit szervezetek és más szociális partnerek szerepét, valamint az intézményi erőforrásokat; harmadrészt pedig az egyes országokban tapasztalható különböző megközelítések hatásait és hatékonyságát. ${ }^{35}$ A vizsgálatok során készült országjelentések ${ }^{36}$ alátámasztották, hogy jelentős különbségek vannak a napközbeni kisgyermekellátás és -nevelés struktúráját tekintve az egyes tagországok között. Ezeket áttanulmányozva megállapítható, hogy alapvetően két modell létezik, az osztott és az egységes rendszer (Korintusné, 2000).

Az osztott rendszert működtető országokban a három év alatti gyermekek ellátása az egészségügyhöz tartozik, a három év felettieké az oktatásügyhöz (ilyen például Franciaország vagy Olaszország). Az egységes struktúrán belül alapvetően két formát lehet megkülönböztetni: az oktatáshoz vagy a szociális szférához tartozót. Az egységes és az oktatásügyhöz tartozó rendszer esetében a pedagógus látja el a 0-6 éves korú gyermekek gondozását-nevelését (például Svédország, Spanyolország). Szintén egységes, azonban a szociális szférához tartozó rendszer müködik például Dániában, ahol egyrészt pedagógusok foglalkoznak a gyermekkel az egész iskolai időszakot megelőzően, másrészt viszont kisiskolás korban szociálpedagógusok látják el a gyermekek délutáni

\footnotetext{
${ }^{34}$ Az összehasonlító vizsgálatban részt vevő országok Ausztrália, Belgium, Csehország, Dánia, Finnország, Olaszország, Hollandia, Norvégia, Portugália, Svédország, az Egyesült Királyság és az Egyesült Államok voltak.

35 A vizsgálatok kapcsán szakértői delegációk tettek látogatást a részt vevő országokban, a tapasztalatok nyomán készült összehasonlító tanulmányt pedig egy nemzetközi konferencia keretében mutatták be 2001-ben. Ugyanebben az évben döntöttek arról, hogy folytatva a szakmapolitikai irányelvek és szolgáltatások megismerését, újabb - a kutatáshoz önként csatlakozó - országokban tesznek a delegációk rövidebb-hosszabb látogatást a kisgyermekkori vizsgálatok céljával. A hosszabb - átfogóbb - vizsgálat mellett döntött többek között Magyarország, Németország és Spanyolország, míg a rövidebb vizsgálatot kérte Franciaország, Írország és az Egyesült Királyság.

${ }^{36}$ Elérhetőek az alábbi oldalon: http://eacea.ec.europa/education /eurydice/index eng.php (2012. 11. 30.)
} 
felügyeletét, a különféle szabadidős tevékenységek szervezését, ami kiterjed a napközi otthonos nevelés keretében megvalósuló tanulási tevékenységre is.

A legtöbb országban a „gondozásra” és a „nevelésre-oktatásra” vonatkozó politika egymástól függetlenül alakult ki, külön szabályozással, finanszírozással és képzéssel a dolgozók számára, míg néhány országban megvalósult a gondozás és nevelés elvi és gyakorlati integrálása. Nemzetközileg egyre gyakoribb, hogy az oktatáspolitikai döntéshozók biztosítani igyekeznek a tanulás folyamatosságát, valamint a rendelkezésre álló erőforrások minél hatékonyabb felhasználását. A koherens kisgyermekkori tapasztalatok kétségkívül megkönnyítik a gyermekek számára az egyik életszakaszból a másikba való átmenetet, biztosítják fejlődésük folyamatosságát (Korintusné, 2002).

Sok országban gondot fordítanak arra, hogy a szülőket bevonják a iskolai nevelőmunkába. Ennek célja egyrészt, hogy a gondozó, a nevelő kiaknázhassa a szülőnek/gondviselőnek a gyermekről való sajátos ismereteit; pozitív attitüdöt és magatartást alakítson ki a gyermekek tanulása iránt, információval lássa el a szülőket, másrészt, hogy erősítse az intézménynek a szülőkkel és a helyi közösséggel való együttmüködését.

Több országban a gyermekek törvényben foglalt joga, hogy hároméves (vagy még fiatalabb) kortól napközbeni kisgyermekellátásban részesüljenek. Az a tendencia, hogy három- és hatéves kor között teljes körü legyen a részvétel, lehetőséget adva a kötelező iskolakezdés előtt legalább két év ingyenes, államilag finanszírozott ellátásra (Korintusné, 2002). A gyerekek az általános iskolát általában négy- és hétéves kor között kezdik, azaz több országban a gyermekek legalább három évet valamilyen napközbeni kisgyermekellátás keretében töltenek, míg máshol maximum három évet járhatnak bölcsődébe, óvodába az iskolakezdés előtt (lásd a 2. számú táblázat adatait).

Az Eurydice gondozásában megjelent összefoglaló tanulmány (Pre-school and primary education in the European Union, 1994) részletesen bemutatja az iskola előtti nevelés, az alapfokú oktatás, valamint az alap- és középfokú oktatás közti átmenet sajátosságait az Európai Unió országaiban. ${ }^{37}$

\section{Az óvoda-iskola átmenetet befolyásoló rendszerszintü indikátorok}

Azt gondolom, az óvoda-iskola átmenet szempontjából központi kérdés, hogy az egyes országokban mi a célja és szerepe a tankötelezettségnek. A mindenkire kiterjedő tankötelezettséget először I. Frigyes Vilmos porosz király vezette be 1717-ben, és csak a 19. században vált általánossá. Európában napjainkban már minden országban, a világ országainak pedig 95 százalékában (Education for All, 2007) van tankötelezettség.

Az iskolába való belépés és kilépés korhatára azonban változó. Az utóbbi évtizedekben - nemzetközi viszonylatban is - jelentős kérdéssé vált, hogy a

\footnotetext{
${ }^{37}$ A dokumentum érinti a tankötelezettség időtartamát, a pedagógusok alapképzését, a tanítási idő beosztását, a szolgáltatások finanszírozását; kitér az oktatási programok elkészítésének folyamatára, a tananyag meghatározására, a tankönyvek és a módszerek kiválasztásának szabadságára, valamint az oktatási programok végrehajtásának és a tanulók tudásának ellenőrzésére.
} 
kötelező alapszintű oktatás melyik életkorban kezdődjön. Az Európai Unió tagállamainak többségében a tankötelezettség 6 éves kortól 16 éves korig tart (14. számú ábra a mellékletben).

A táblázat adatait tanulmányozva láthatjuk, hogy néhány országban a gyerekek négyéves korban kezdik az általános iskolát (például Luxemburg vagy Észak-Írország), másutt öt és fél év a tankötelezettség alsó határa (például Hollandia, Anglia, Wales, Skócia vagy Görögország), s a legkésőbbi iskolakezdési kor a hetedik életév (Dánia, Norvégia).

$\mathrm{Az}$ eltérő iskolakezdési életkor mellett azt is különböző módon szabályozzák az egyes államokban, hogy mely naptári időpontot veszik figyelembe a tankötelezettség megkezdéséhez szükséges négy-, öt- vagy hatéves életkor elérése szempontjából. Észak-Írországban az adott év július 1-jéig kell betöltenie ehhez a gyermeknek a negyedik életévét. Dániában a tankötelezettségi életkort, azaz a hatéves kort augusztus 1-jéig, Olaszországban augusztus 31-ig, Ausztriában szeptember 1-jéig, míg Portugáliában szeptember 15-ig kell betölteni. Angliában és Walesben - a többi ország gyakorlatától eltérően - három napot írnak elö: március 31-et, augusztus 31-et és december 31-et. Ezek közül azt a dátumot követően, amikor a gyermek betölti ötödik életévét, köteles megkezdeni az alapfokú iskolát. Norvégiában azon naptári évben kell iskolába íratni a gyermeket, amelyben betölti a hatodik életévet (Istenes és Péceli, 2010).

Az iskolai tanulás megkezdésének ideális korhatárát tekintve két álláspont látszik körvonalazódni. Az intézményes nevelésben való részvétel mielöbbi megkezdését támogatók elsősorban a hátránykompenzáció, valamint a korrekciós nevelés szempontjából az óvodáztatás kötelezővé tételével (jelenleg ezt a törekvést láthatjuk a hazai közoktatás-politikában), a tankötelezettségi korhatár leszállításával vagy az úgynevezett iskolaelőkészítő vagy nulladik évfolyamok bevezetésével (amint azt Szlovákia pedagógiai gyakorlatában, igaz csak opcionálisan, de megtaláljuk) kívánják előmozdítani azt. A beiskolázási korhatár emelését szorgalmazók pedig leginkább a gyermekek iskolai ártalmaktól való megóvását, a teljesítményorientált iskolai oktatás okozta kudarcok elkerülését kívánják elérni.

1. számú táblázat: Európai országok áttekintése az iskolakezdési életkor szerint

\begin{tabular}{|c|l|}
\hline Iskolakezdési életkor & \multicolumn{1}{c|}{ Európai országok } \\
\hline 4 év & Észak-Írország \\
\hline 5 év & Málta, Egyesült Királyság, Skócia, Wales, Hollandia \\
& $\begin{array}{l}\text { Ausztria, Belgium, Ciprus, Cseh Köztársaság, Franciaország, } \\
\text { Németország, Görögország, Magyarország, Izland, Irország, } \\
\text { Olaszország, Liechtenstein, Litvánia, Luxemburg, Norvégia, } \\
\\
\text { Portugália, Szlovákia, Szlovénia, Spanyolország }\end{array}$ \\
\hline 7 év & $\begin{array}{l}\text { Bulgária, Észtország, Dánia, Finnország, Lettország, } \\
\text { Lengyelország, Románia, Svédország }\end{array}$ \\
\hline
\end{tabular}

Az alapfokú oktatás kezdete általában egybeesik a tankötelezettség alsó korhatárával (vö. 2. számú és 3. számú táblázat adatait). Az Európai Unió 
tagállamainak többségében az alsó tagozat 5-7 éves korban kezdődik és 10-12 éves korig tart, amikor is a gyerekek felső tagozatba lépnek. Dániában erre csak 16 éves korban kerül sor, mivel a 7-16 éves korig terjedő kötelező oktatási periódus - ahogy azt korábban bemutattam - egységes.

Több tagállamban az iskola elötti nevelés és az alapfokú oktatás egészét két vagy akár több ciklusra bontják (Pre-school and primary education in the European Union, 1994; Supplement to the study on pre-school and primary education in the European Union, 1996). Az elemi oktatás több országban önálló ciklusokból áll (Belgium, Olaszország, Portugália), másutt külön szakaszokra bontják az iskola előtti nevelést is. Így Spanyolországban az óvodai nevelés két, míg az elemi oktatás három periódusra oszlik; Franciaországban pedig az iskola előtti nevelés és az alapfokú oktatás háromlépcsős rendszert alkot.

Az egyik osztályból a másikba lépés az alsó tagozaton általában automatikus, nem kötött sem vizsgához, sem pedig tanulmányi eredményhez. A nehézségekkel küzdő diákok számára lehetőség van az osztályismétlésre a legtöbb európai államban (kivéve Dánia, Svédország, Norvégia és Görögország). Évismétlésre az első ciklus alatt egy alkalommal van lehetőség, speciális és egyedi eseteket kivéve (Luxemburg, Hollandia, Belgium, Spanyolország, Portugália, Németország), van, ahol az évismétlésről szóló döntést indokolni kell (Olaszország). Kivétel Franciaország, ahol többször is lehetőség van az osztályismétlésre. Ausztriában csak az első osztályból a másodikba való átlépés automatikus, a többi osztályban a tanulmányi teljesítményhez kötik a továbbhaladást.

Az európai uniós tagállamok közel felében a gyerekek 12 éves korukban fejezik be alapfokú tanulmányaikat. Egyes országokban ez a periódus hamarabb, már 10 éves korban lezárul (Ausztria, Németország, azonban ez utóbbi két tartományában, Berlinben és Brandenburgban, az alsó tagozat 2 évvel hosszabb), máshol 11 éves (Franciaország, Olaszország és Skócia kivételével az Egyesült Királyság) vagy 13 éves korig tart (Norvégia).

Minden egyes uniós tagállamban lehetőségük van a szülöknek arra, hogy gyermeküket állami iskolába vagy magánintézménybe írassák, azaz egyrészt intézményalapítási pluralizmus, másrészt intézményválasztási autonómia van. Az állami intézmények általában világi jellegüek, míg a magánszférába tartozók többfélék lehetnek. Megtalálható egyházi jellegü, alternatív pedagógiai módszerekkel müködő, az állami iskoláknak megfelelő, de a privát szektor által fenntartott, valamint az állammal szerződéses viszonyban álló iskola egyaránt (Szabó, 2000). Az állam által finanszírozott magánintézményeknek minden esetben eleget kell tenniük bizonyos müködési alapfeltételeknek, ilyen például az oktatási program elkészítése vagy a minimális tanítási idő betartása, mindezeket országonként törvények is szabályozzák. A magániskolákat azonban az adott oktatási hatóságok nagyon különbözö módokon ellenőrizhetik. Különbségek vannak a tagállamok között a magánszféra szerepét illetően is. Az alapfokú oktatásban tanulók több mint fele (Hollandia), másutt viszont e korosztálynak mindössze töredéke tanul magániskolában (Németország, Írország). 
A gyerekek napközi otthonos elhelyezésének igénye egyre gyakoribb, mivel nemcsak a nők nagyobb arányú munkába állásával kell számolni, hanem ezzel egy időben a hagyományos családi struktúrák felbomlásával is (Szabó, 2000; Preschool and primary education in the European Union, 1994; Supplement to the study on pre-school and primary education in the European Union, 1996). Európai szintü probléma, hogy a fiatal szülők nem számíthatnak szélesebb családi segítségre. Ennek több oka is lehet, talán a leggyakoribb a többgenerációs családok hiánya, a nagyszülők aktív munkavállalói léte (akár nyugdíjas státus mellett is), vagy a mobilitás miatti nagy távolságok a gyermekek és a szülők lakóhelyét illetően (határokon belül és határokon túl is!). Az egyszülős családokban a gyerekek felügyelete nagyobb nehézséget okoz, így vannak országok, ahol bizonyos szolgáltatások kifejezetten a nehéz szociális körülmények között élö gyerekek számára jöttek létre. Ilyen céllal néhány országban a tanítási időn túl szervezett tevékenységeket is biztosítanak a gyermekek számára. Ezek gyakran csak kísérleti projektben megvalósított tevékenységek (Belgium, Németország, Franciaország, Görögország, Hollandia, Portugália, Egyesült Királyság), de például Dániában az ilyen jellegü tevékenységeket az iskolákkal szorosan együttmüködő szabadidőközpontokban (SFO) rendszeresen szervezik meg.

Az Európai Unió tagállamaiban az iskola elötti nevelés közös célkitüzése a gyermekek szocializálása, hozzászoktatása a társas-közösségi élethez (Pre-school and primary education in the European Union, 1994; Supplement to the study on pre-school and primary education in the European Union, 1996). Egyes országokban (mint például Németország, Írország, Hollandia, Ausztria) az iskola előtti nevelést folytató intézmények elsődleges szerepe a családi nevelés kiegészítése, a pedagógusok a gyermekek szocializációjáért és kibontakoztatásáért felelősek, konkrét tanítási feladatot nem látnak el. Más országokban (Belgium, Franciaország, Luxemburg, Görögország, Olaszország, Spanyolország) hangsúlyos szerepet kap az óvodai nevelésben a gyermekek fokozatos felkészítése az iskolai életre.

\section{A pedagógusképzés sajátosságai}

Széles körben elfogadott, hogy a kisgyermekellátásban és -nevelésben dolgozóknak - pedagógusoknak és a technikai dolgozóknak egyaránt - jelentős hatásuk van a gyermekek fejlődésére. A pedagógusok alapképzésének időtartama és színvonala államonként változó, ráadásul az iskola előtti nevelésben részt vevő és az elemi szinten tanító pedagógusok képzése gyakran elválik egymástól.

Az óvodapedagógusi és tanítói tanulmányok megkezdéséhez majdnem minden tagállamban a középiskolai tanulmányok befejezését igazoló bizonyítvány szükséges. A három-, négy- vagy ötéves képzés végén az óvodapedagógusok (Spanyolország, Görögország, Franciaország, Finnország, Svédország és az Egyesült Királyság kivételével) felsőfokú, de nem egyetemi végzettséget szereznek. A tanítóképzés sok országban egyetemi szintü. A képzés időtartama országonként változik, általában négyéves, de van, ahol csak hároméves, és van, 
ahol öt évre tolódik ki (Szabó, 2000; Pre-school and primary education in the European Union, 1994; Supplement to the study on pre-school and primary education in the European Union, 1996).

\section{Záró gondolatok}

E rövid kitekintésből is érzékelhető talán, hogy Európa-szerte tendencia egyrészt az oktatási rendszerben kötelezően eltöltendő évek számának emelkedése és csökkenése; másrészt mind a tankötelezettség alsó, mind felső korhatára mozgásban van, mindkettő lefelé, illetve felfelé egyaránt. Az összehasonlíthatóság, a közös fejlesztési törekvések megfogalmazása kapcsán fontos szemponttá vált a tankötelezettség időtartalmának növelése mellett az oktatási rendszerek egységes elveken nyugvó osztályozása (ISCED rendszer), valamint a szakképzettség megszerzésének „,egységesítése” (bolognai többciklusú képzési rendszer).

A tankötelezettségi korhatár módosítása szerkezeti változtatás, avagy tüneti kezelés? Továbbgondolásra érdemes, mire jó önmagában a tankötelezettség, és milyen más intézkedésekkel együtt érheti el hatékonyabban célját. Érdemes lenne ezekre a kérdésekre európai szintű összehasonlító vizsgálat során válaszokat keresni, erre jelen tanulmány keretei között nem vállalkozhattam, de azt gondolom, csupán e kérdéskör hazai szintü vizsgálata eredményesebbé tehetné a jelenkori köznevelési szabályozókat.

Összegezve megállapítható, hogy az egyes európai tagállamok különböző mértékben ismerték fel, hogy a gyermekkori nevelési minősége olyan kritikus tényező, amely a megfelelő finanszírozástól, a pedagógiai kutatási eredmények gyakorlatba történő átültetésétől, a minőségi garanciáktól és a pedagógusok folyamatos képzésétől is függ. Azok az európai országok, ahol van az iskoláskort megelőző intézményes nevelési forma, többségében kiemelkedő részvételi mutatókkal rendelkeznek. Ennek ellenére e szolgáltatások minősége és elérhetősége sok országban fejlesztésre szorul. A minőségi gyermekkori gondozáshoz-neveléshez-oktatáshoz elengedhetetlen az optimális feltételek megteremtése. Alapvetően meghatározó tényezők: a pedagógusok alapképzettsége és továbbképzési lehetőségeik biztosítása; az intézményes nevelési formák és az otthon nevelés harmóniája, együttműködése; valamint olyan strukturális feltételek, mint például a csoportméret vagy a pedagógiai munkát segítő alkalmazottak szakképzettsége és kellő mértékű jelenlétük biztosítása az intézményes nevelés folyamatában.

\section{Jegyzetek}

Education for All by 2015 - Will we make it? Education for All Global Monitoring Report 2008 (2007) UNESCO, Oxford University Press: Oxford. http://unesdoc.unesco.org/images/0015/001547/154743e.pdf (2010. 01. 08.)

Pre-school education: current thinking and provision. (1995) ECSC-EC-EAEC: Brussels - Luxembourg.

Pre-school and primary education in the European Union. (1994) EURYDICE EUROPEAN UNIT: Brussels. 
Supplement to the study on pre-school and primary education in the European Union. The situation in Austria, Finland and Sweden and in the EFTA/EEA countries. (1996) EURYDICE EUROPEAN UNIT: Brussels.

Bajomi Iván (1991): Egy törvény margójára. In: Setényi János (szerk.): A francia oktatási kerettörvény. Oktatási törvénykezés Európában sorozat. Educatio Kiadó, Budapest. 510.

Broström, Stig (2000a). Communication \& Continuity in the Transition from Kindergarten to School in Denmark. http://www.extranet.edfac.unimelb.edu.au (2009. 08. 08.)

Broström, Stig (2000b). Transition to School. http://www.eric.ed.gov/PDFS/ ED445814.pdf (2011. 02. 01.)

Ionescu, Thea - Benga, Oana (2007). Reconceptualizing early education on scientific grounds: school readiness in focus. In: Cognition, Brain, Behavior, 11. 1. 49-65.

Istenes Mónika - Péceli Melinda (2010): Tankötelezettségi korhatárok nemzetközi összehasonlításban. In: Iskolakultúra, 20. 4. 3-22.

Korintus Mihályné (2002): Az OECD-országok kisgyermekneveléssel és -ellátással kapcsolatos politikája. In: Új Pedagógiai Szemle, 52. 12. 117-126.

Leroy-Audouin, Christine (1995): La transition école maternelle - école élémentaire pour les enfants «en avance»: du passage anticipé en Cours préparatoire au cycle des apprentissages fondamentaux. In: Enfance, 48. 1. 3-24.

Sharp, Caroline (2002). School Starting Age: European Policy and Recent Research. http://www.emie.ac.uk/nfer/publications/44414/44414.pdf (2011. 12. 29.)

Šmelová, Eva - Souralová, Eva (2010). School Readiness of Children in the View of Preschool Pedagogues. In: Buletinul Universităţii Petrol - Gaze din Ploieşti, 62. 1 B. sz. 98-106.

Straková, Jana - Simonová, Jaroslava - Polechová, Pavla (2011). Overcoming School Failure Background Report for the Czech Republic. http://www.oecd.org/education/preschoolandschool/48631810.pdf (2012. 01. 08.)

Szabó Balázs Gábor (2000, vál. és szerk.): Az iskola előtti nevelés és az alapfokú oktatás az Európai Unióban. In: Új Pedagógiai Szemle, 50. 2. 112-124.

Tymms, Peter - Jones, Paul - Merrell, Christine - Henderson, Brain - Cowie, Mike (2005). Children starting school in Scotland. Scottish Executive Education Department, Edinburgh. http://www.scotland.gov.uk/Resource/Doc/36496/ 0009634.pdf (2012. 01. 02.) 


\section{Mellékletek: Az európai oktatási rendszerek bemutatása ${ }^{38}$}

\section{1. ábra ${ }^{39}:$ Az oktatási rendszer nemzetközi rendszeresített osztályozása (ISCED $)^{40}$}

\begin{tabular}{|c|c|c|}
\hline $\begin{array}{l}\text { Iskola előtti nevelés } \\
\text { (nem az oktatási minisztérium felügyeli) }{ }^{41}\end{array}$ & Alapfokú oktatás & $\begin{array}{l}\text { Tankötelezettség } \\
\text { (nappali képzésben) }\end{array}$ \\
\hline $\begin{array}{l}\text { Iskola előtti nevelés } \\
\text { (az oktatási minisztérium felügyeli) }\end{array}$ & Egységes szerkezet & III ISCED 0 世ा ISCED 1 \\
\hline
\end{tabular}

\section{2. ábra: Anglia oktatási rendszere}

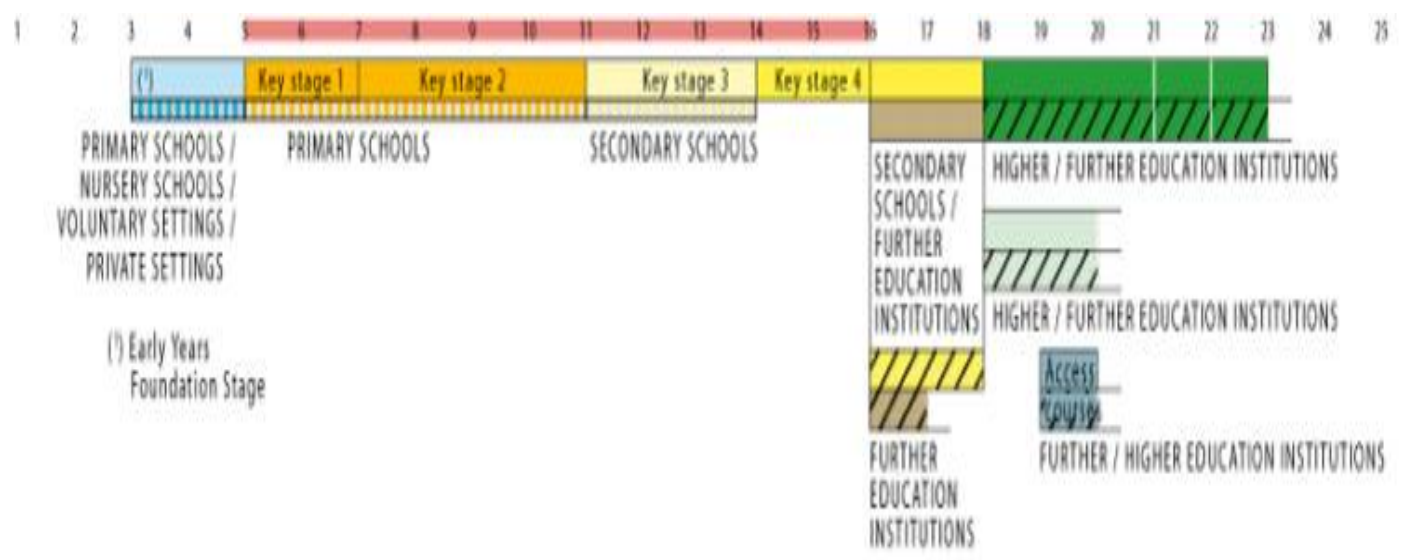

3. ábra: Wales oktatási rendszere

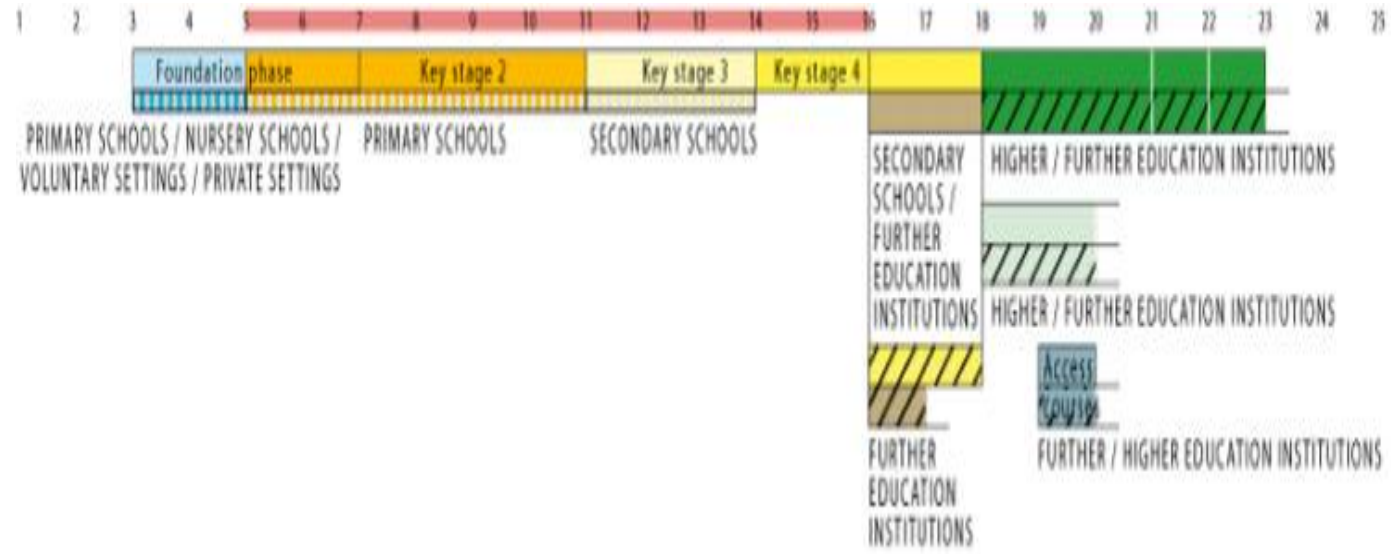

${ }^{38}$ Forrás: https://webgate.ec.europa.eu/fpfis/mwikis/eurydice/index.php?title=Countries

39 A jelmagyarázatban szereplő kifejezések az angol fogalmak általam készített értelmező fordításai. Az eredeti jelmagyarázat az alábbi oldalon tekinthető meg:

http://eacea.ec.europa/education/eurydice/index eng.php

40 ISCED (International Standard Classification of Education): Az oktatási rendszer nemzetközi rendszeresített osztályozása, ISCED 0: iskola elötti nevelés szintje, ISCED 1: alapfokú oktatás szintje.

$41 \mathrm{Az}$ összehasonlíthatóság érdekében az iskola előtti nevelésnél az oktatási minisztérium kifejezést használom az angol nyelvü forrás tükörfordításaként, megjegyezve, hogy az oktatási ügyekkel foglalkozó minisztériumok országonként eltérő elnevezéssel, eltérő államigazgatási struktúrában vannak jelen. 
4. ábra: Skócia oktatási rendszere

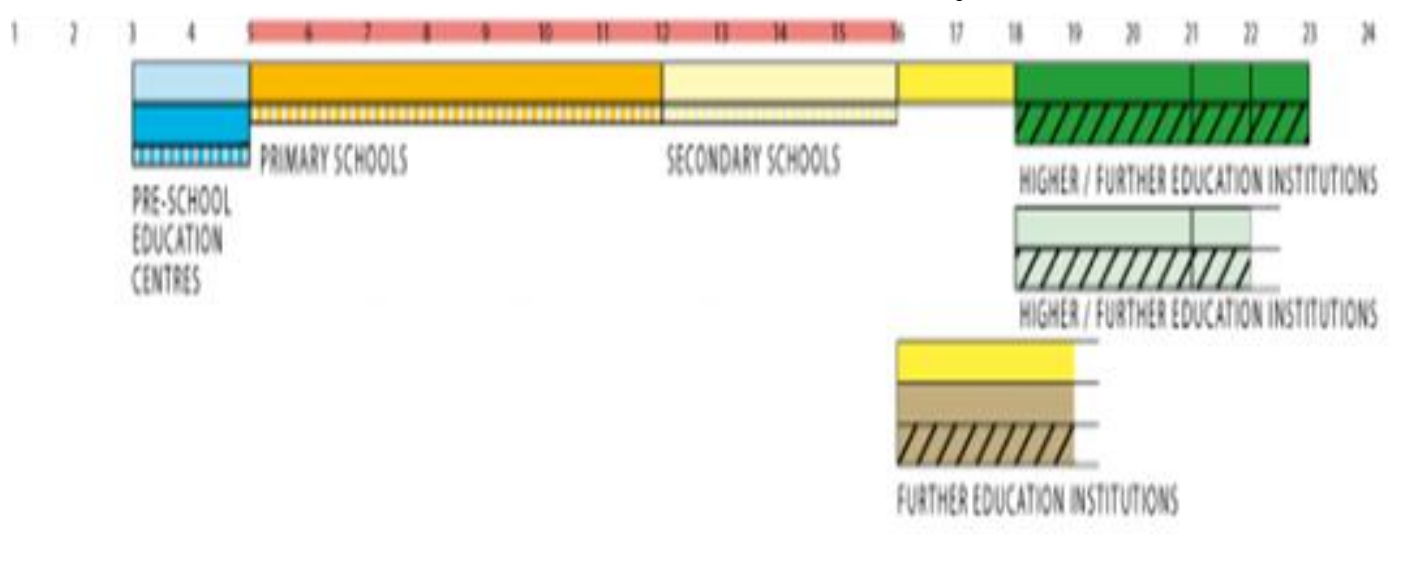

5. ábra: Észak-Írország oktatási rendszere

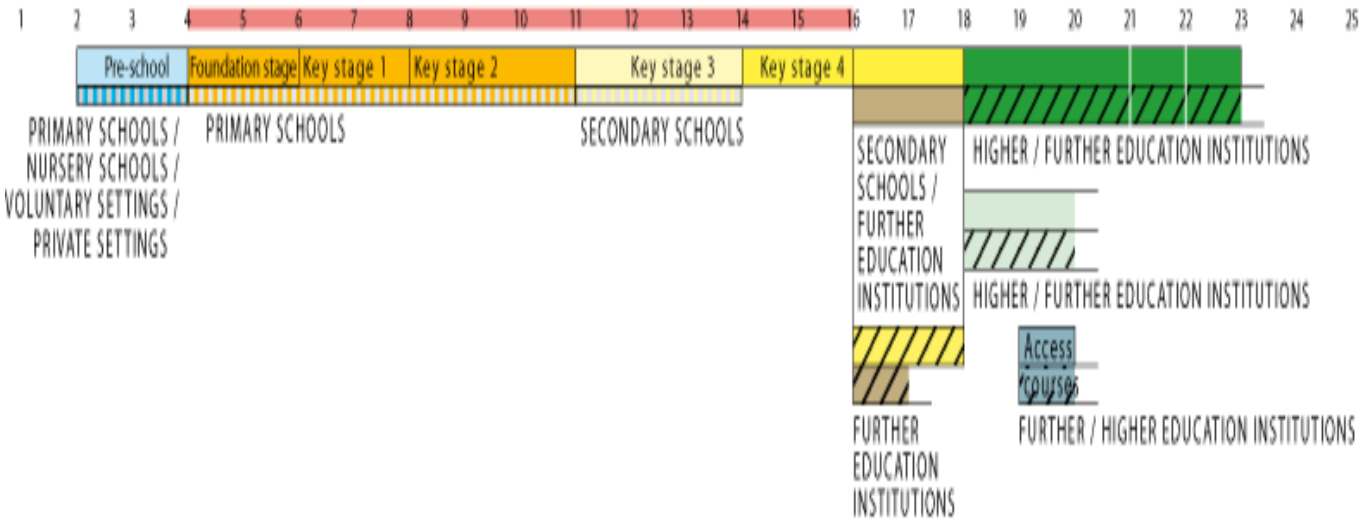

6. ábra: Dánia oktatási rendszere

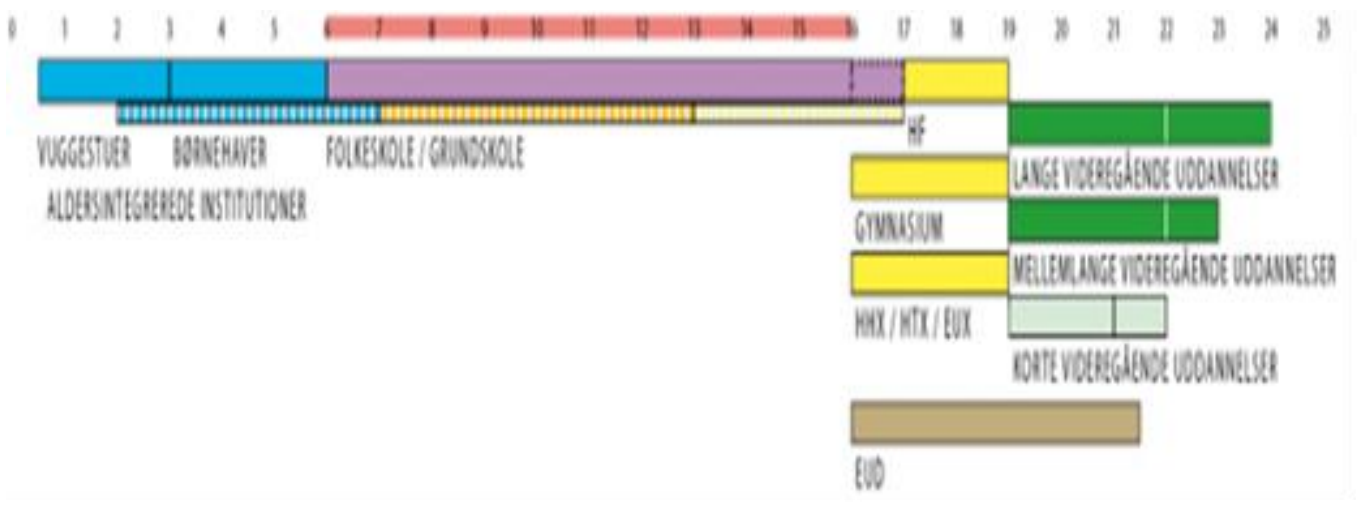


7. ábra: Németország oktatási rendszere

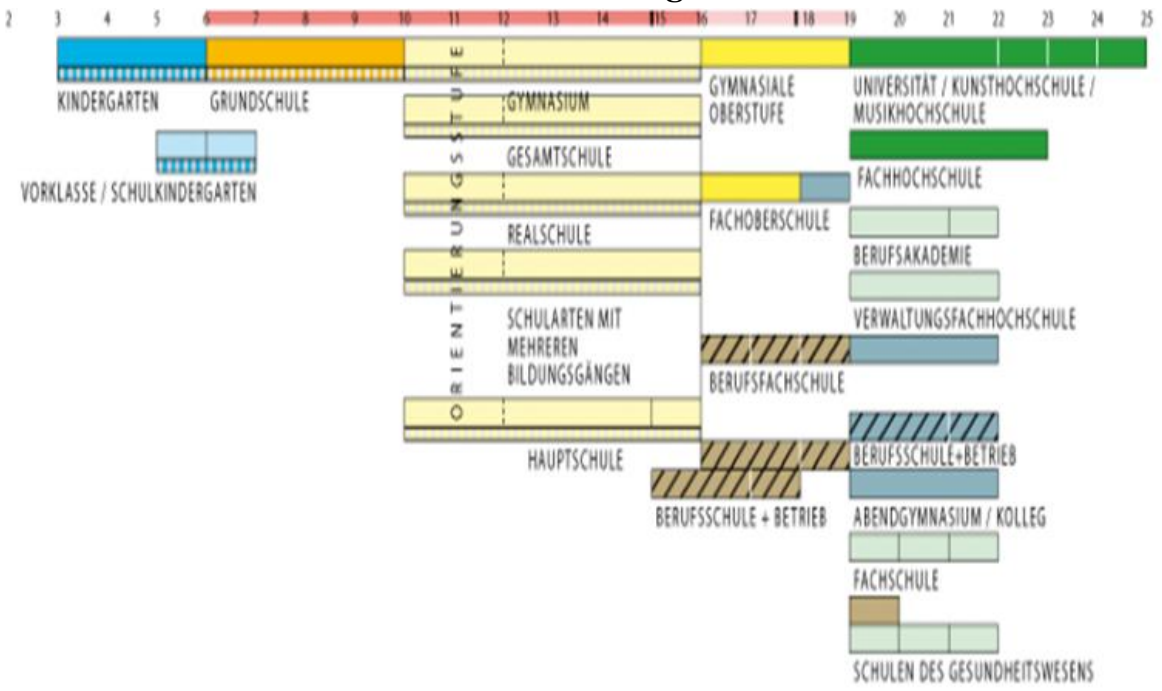

8. ábra: Spanyolország oktatási rendszere

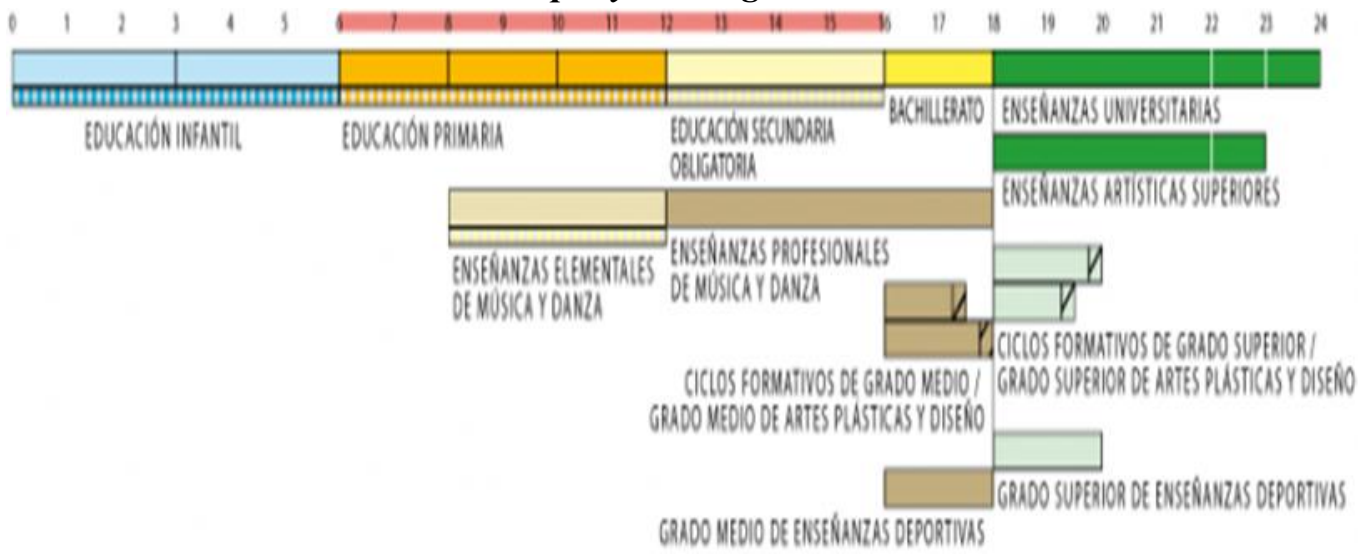

9. ábra: Franciaország oktatási rendszere

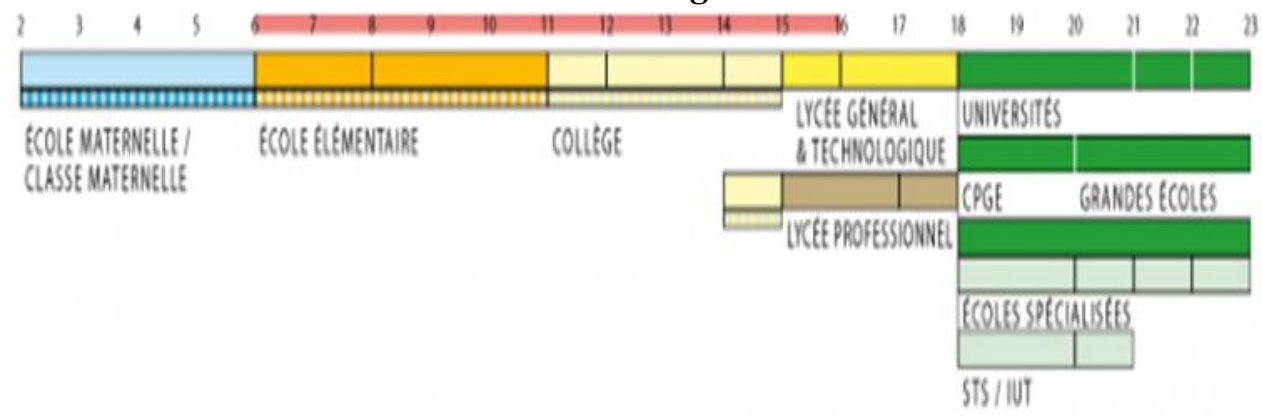


10. ábra: Írország oktatási rendszere

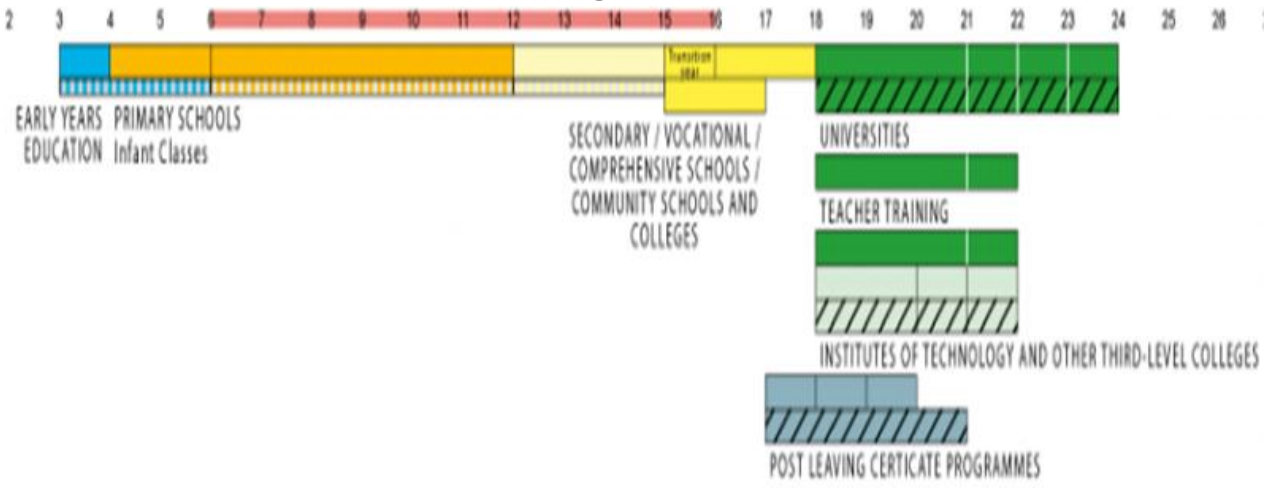

11. ábra: Románia oktatási rendszere

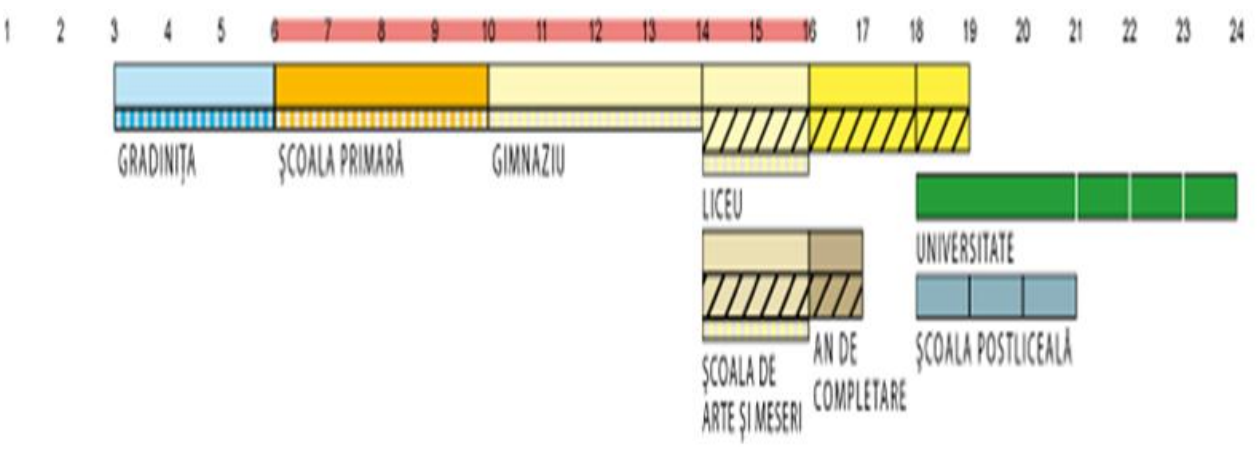

12. ábra: Csehország oktatási rendszere

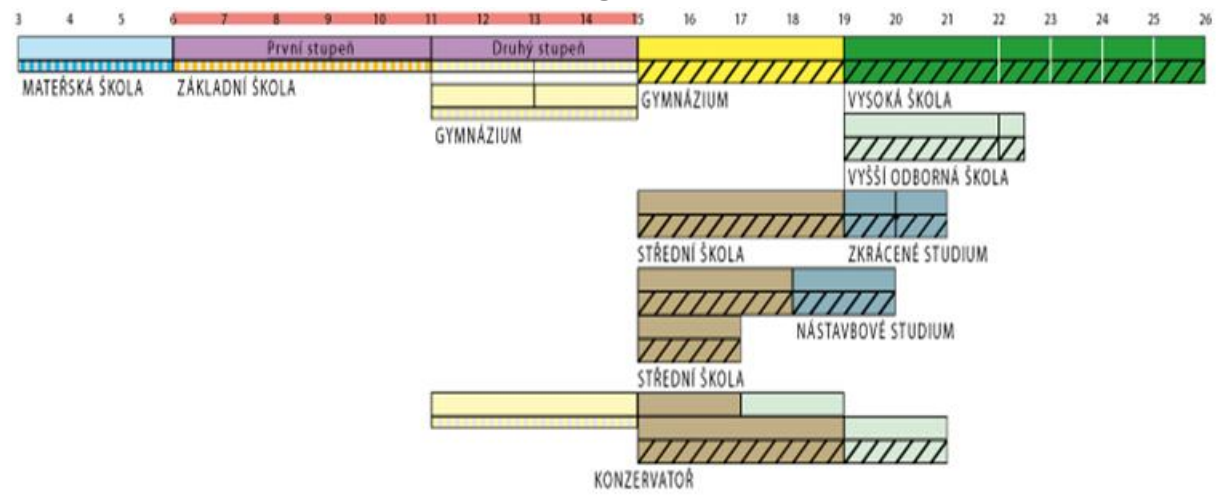

13. ábra:Szlovákia oktatási rendszere

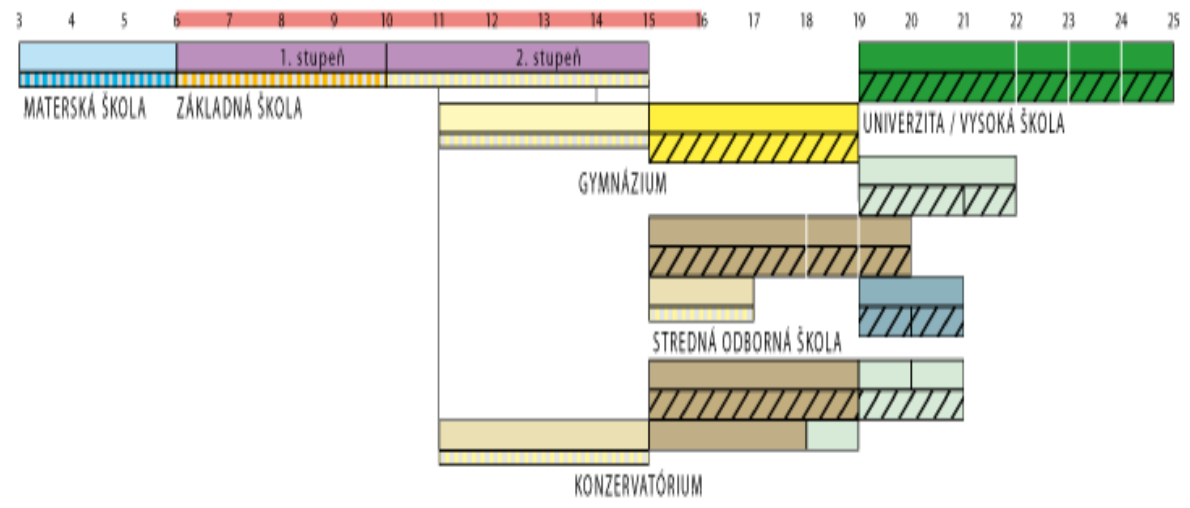




\section{4. ábra: Tankötelezettség Európában}

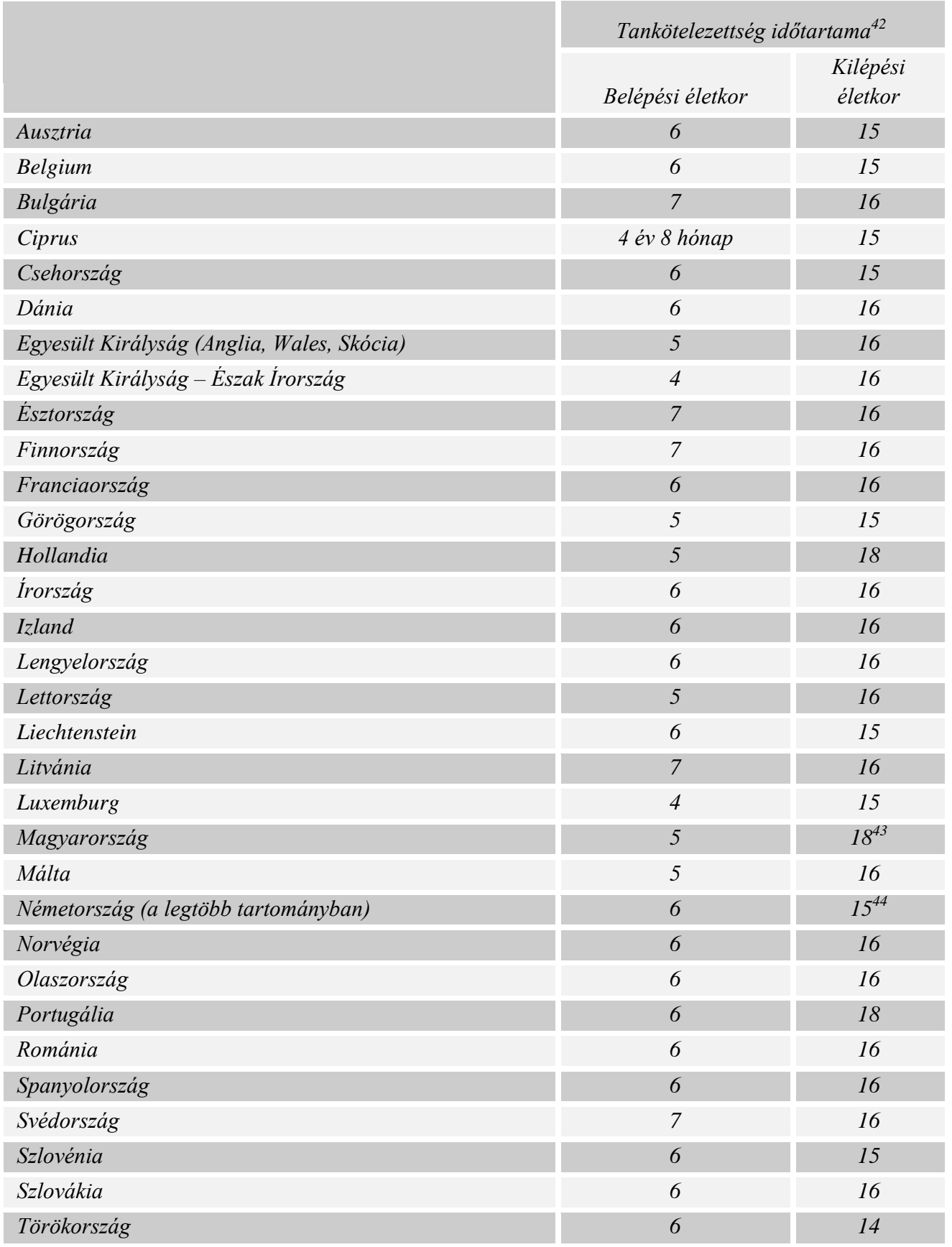

42 A legtöbb európai országban azonos a tankötelezettség időtartama minden képzési formában tanuló számára. Néhány európai országban azonban eltérő a nappali képzési rendszerben és a nem nappali képzési rendszerben részt vevők tankötelezettsége. Így Belgiumban, Németország legtöbb tartományában, valamint Portugáliában a nem nappali képzési rend szerint tanulóknak 18, míg Németország néhány tartományában 19 éves korig tart a tankötelezettség.

43 A nemzeti köznevelési törvény (2011) értelmében 2013. január 1-jétől lép hatályba a tankötelezettséget érintő új szabályozás, amely a 16. életévben határozza meg az tankötelezettség felső korhatárát Magyarországon.

${ }^{44}$ Néhány tartományban 16 éves kor a tankötelezettség felső korhatára. 